\title{
Retroplacental Thrombus
}

National Cancer Institute

\section{Source}

National Cancer Institute. Retroplacental Thrombus. NCI Thesaurus. Code C117331.

A focus of retroplacental thrombus variably extending into the intervillous space, often with peripheral villous compression. The clot may be wholly or minimally laminated reflecting age. 